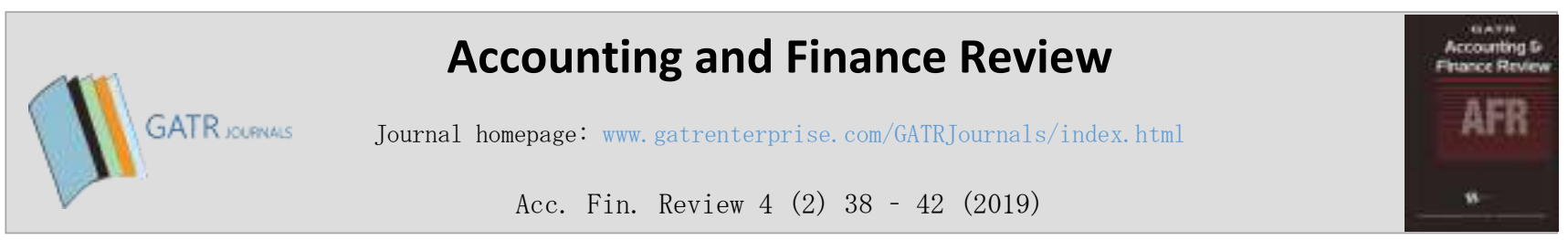

\title{
Ownership Structure and Earnings Management
}

\author{
Nico Alexander \\ Trisakti School of Management, Kyai tapa No. 20, 11440, Jakarta, Indonesia
}

\begin{abstract}
Objective - The purpose of this research is to analyze the effect of ownership structure toward earnings management. Methodology/Technique - The population of this research consist of manufacturing companies listed on the Indonesian Stock Exchange (IDX) from 2014 to 2016. This research uses 3 recent years and adds variables that have not been used in prior research. The sample of this research is chosen using a purposive sampling method.

Findings - The hypothesis is tested by multiple regressions using an Eviews program to investigate the influence between each independent variable to earnings management.

Novelty - The research results shows that institutional ownership, controlling ownership, and foreign ownership affect earnings management whilst managerial ownership has no effect on earnings management.
\end{abstract}

Type of Paper: Empirical.

Keywords: Earnings Management; Ownership Structure; Institutional Ownership; Controlling Ownership; Foreign Ownership.

Reference to this paper should be made as follows: Alexander, N.; (2019). Ownership Structure and Earnings Management, Acc. Fin. Review, 4 (2): 38 - 42 https://doi.org/10.35609/afr.2019.4.2(1)

JEL Classification: G40, G41, G49.

\section{Introduction}

The separation of ownership and control in firms is common in business. When a firm is listed on the stock exchange, the structure of its' ownership will be more complicated than those of non-public firms. However, this kind of separation creates serious conflicts between the shareholders and the management of a company. Management are typically motivated to obtain bonuses for themselves rather than transferring that wealth to the owner of the company (Ali et. al., 2008). The separation of ownership structure has two different consequences for earnings quality.

\footnotetext{
* Paper info: Revised: March 10, 2019

Accepted: July 10, 2019

* Corresponding author: Nico Alexander

E-mail: nico@stietrisakti.ac.id

Affiliation: Trisakti School of Management, Kyai tapa No. 20, 11440, Jakarta, Indonesia
} 
According to the "demand" hypothesis, public firms have a higher earnings quality compared to private firms. This is due to the demand of shareholders and creditors for high quality reporting. On the other hand, the "opportunistic behavior" hypothesis states that firms with a diffused ownership structure typically have lower earnings quality because their managers have higher incentives to manipulate earnings (Bartov et. al., 2010).

Ownership structure can be seen in several levels of ownership (i.e. insider ownership and outsider ownership). In this research, managerial, institutional, controlling and foreign ownership is examined. Research concerning ownership structure and earnings management has achieved inconsistent results, which the present research aims to address. The purpose of the present research is therefore to identify and examine the effect that managerial, institutional, controlling, and foreign ownership have on earnings management.

\section{Literature Review}

\subsection{Agency Theory}

Agency theory involves the management (agent) and the investor (principal). The principal has reason to believe that the agent will always act on behalf of their interests (Godfrey et. al., 2010). However, agency problems often arise. According to Charitou et. al. (2016), agency conflicts are divided into two types: type I, which refers to conflict between shareholders and managers and type II, which refers to conflict between the majority and minority shareholders.

\subsection{Institutional Ownership Towards Earnings Management}

Institutional ownership is the ownership of company shares by institutions (pension funds, investment companies, banks and others). The relationship between institutional ownership and the quality of financial reporting is the fact that institutional ownership can improve the supervision of management by minimizing agency conflicts between shareholders and managers (Affan et. al. 2017). According to Bhatala et. al. (1994), Affan et. al. (2017) and Sirat (2012), institutional ownership has an influence on monitoring the behavior of corporate managers and can therefore minimize agency conflicts between shareholders and manager and consequently minimize agency problems. From the explanation above, the following hypothesis is proposed:

H1: Institutional Ownership has a negative effect on Earnings Management.

\subsection{Managerial Ownership Towards Earnings Management}

Managerial ownership is the amount of shares owned by the management. According to Imoleayo et al., (2017), Ogbonnaya et. al., (2016), Warfield et. al., (1995) and Guna and Herawaty (2010), managers who own company shares may contribute to a higher level of earnings management practices. This is because managers will be motivated to improve the earnings quality of the company so that they can obtain the maximum benefit. From the explanation above, the following hypothesis is proposed:

H2: Managerial Ownership has a positive effect on Earnings Management.

\subsection{Controlling Ownership Towards Earnings Management}

Controlling ownership refers to those stakeholders holding the largest portion of the shares in a company. Controlling shareholders use financial information for their personal benefit and tend to be more active in the company to achieve their objective of maximizing the return on their investment (Imoleayo et. al., 2017). Controlling shareholders use their significant influence over management to manipulate the accounting information (Bao \& Lewellyn, 2017). From the explanation above, the following hypothesis is proposed: 
H3: Controlling Ownership has a positive effect on Earnings Management.

\subsection{Foreign Ownership Towards Earnings Management}

Foreign ownership refers to the portion of shares held by foreign investors, i.e. companies owned by individuals, legal entities, the government, and their sections of foreign status. The greater the shares controlled by foreign parties, the more foreign representatives are appointed within the company, either on the board of commissioners or the board of directors. They aim to align the interests of management and shareholders to improve the quality of the financial reporting (Wiranata \& Nugrahanti 2013). From the explanation above, the following hypothesis is proposed:

H4: Foreign Ownership has a negative effect on Earnings Management.

\section{Research Methodology}

The population used in this research includes manufacturing companies listed on the Indonesian Stock Exchange between 2014 to 2016. The sample selection techniques used in this research is purposive sampling. This resulted in the selection of 36 companies. To test the hypotheses, multiple regression is used.

\subsection{Definition Operation}

Earnings management is measured using the discretionary accruals developed by Dechow et. al. (1995). Institutional ownership refers to the ownership of company shares by institutions (pension funds, investment companies, banks and others). Managerial ownership refers to the shares owned by management. Controlling ownership refers to the stakeholders holding the largest proportion of the shares. Foreign ownership is measured by dummy variable 1 if there is a portion where the outstanding shares are held by foreign investors, i.e. companies owned by individuals, legal entities, the government, and their sections of foreign status and 0 otherwise.

The research framework of this research is shown below:

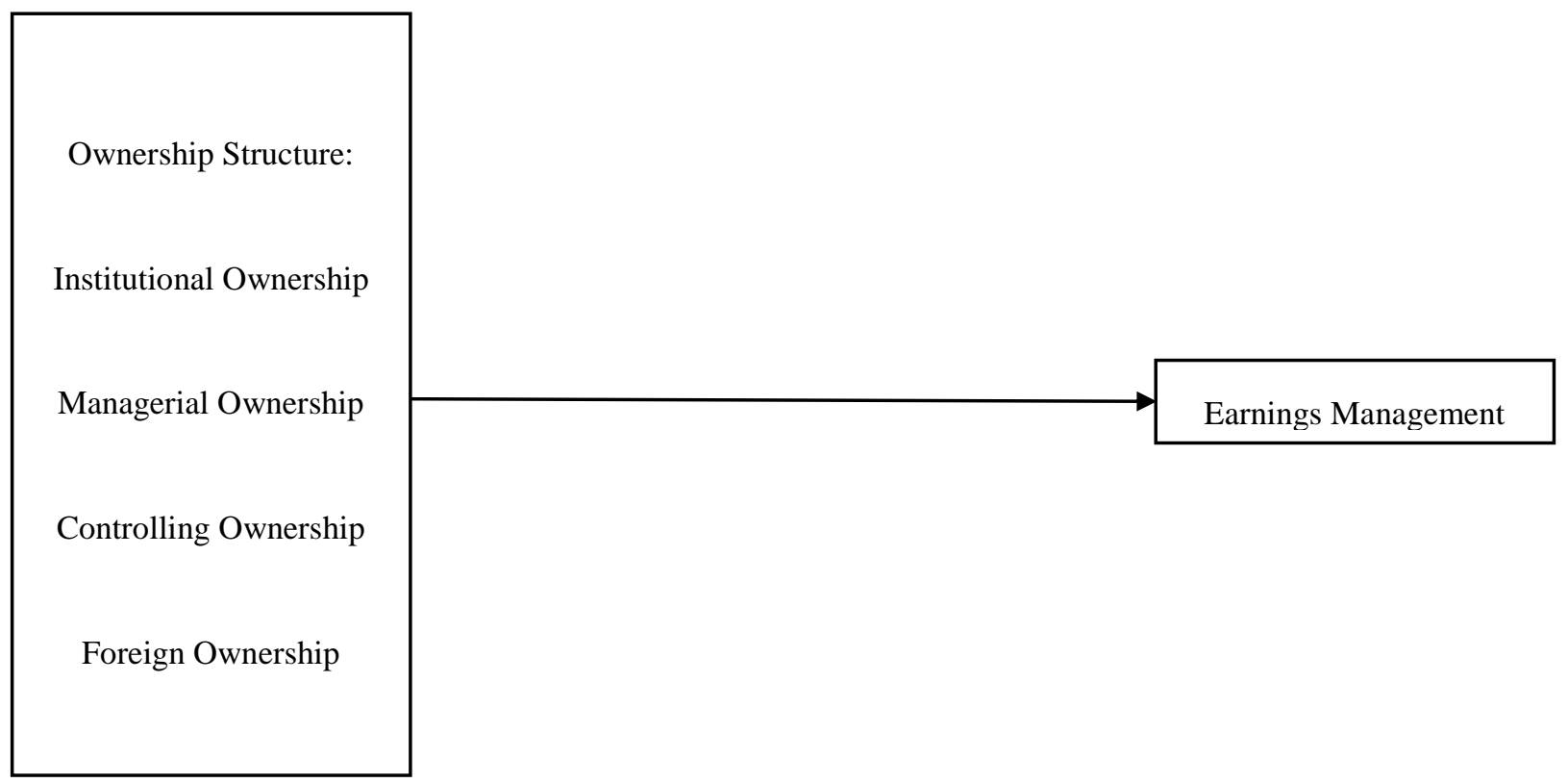


Figure 1. Research Framework

\section{Results}

Table 1 and Table 2 below show the descriptive statistic and hypothesis results.

Table 1. Descriptive Statistics

\begin{tabular}{cccccc}
\hline & $\mathrm{N}$ & Minimum & Maximum & Mean & Std. Deviation \\
\hline DACC & 108 & 0.001670 & 0.621270 & 0.187152 & 0.129822 \\
INSTITUTIONAL & 108 & 0.000000 & 0.980011 & 0.623575 & 0.238929 \\
MANAGERIAL & 108 & 0.000000 & 0.739138 & 0.038964 & 0.103578 \\
CONTROLLING & 108 & 0.152900 & 0.894700 & 0.459593 & 0.195263 \\
FOREIGN & 108 & 0.000000 & 1.000000 & 0.537037 & 0.500951 \\
\hline
\end{tabular}

Table 2. Hypothesis Results

\begin{tabular}{ccc}
\hline Variable & $\mathrm{B}$ & $\mathrm{t}$ \\
\hline (Constant) & 0.227443 & 4.224419 \\
INSTITUTIONAL & 0.136566 & $2.061273^{*}$ \\
MANAGERIAL & -0.074238 & -0.503411 \\
CONTROLLING & -0.199201 & $-2.747748^{*}$ \\
FOREIGN & -0.057736 & $-2.074334^{*}$ \\
\hline Adjusted R-squared & & 0.059762 \\
F-statistic & & 2.700247 \\
Prob(F-statistic) & & 0.034638 \\
\hline
\end{tabular}

\section{Discussion}

From Table 2, it can be seen that institutional ownership has a positive effect on earnings management. It shows that the more institutional ownership in a company, the more likely it is that management will conduct earnings management to obtain more wealth from its investment in a company. Furthermore, controlling ownership and foreign ownership have a negative effect on earnings management. According to the "demand" hypothesis, public equity firms have a higher quality of earnings than private equity firms due to stronger demand by shareholders and creditors for quality reporting. Hence, a higher level of foreign ownership will reduce the prevalence of earnings management practices.

\section{Conclusion}

The purpose of this research is to obtain empirical data on the effect of the structure of ownership toward earnings management. The sample used in this research includes 108 data sets. The results show that of the 4 variables, institutional ownership has a positive effect on earnings management. This means that the more institutional ownership in a company, the more likely it is that management will engage in earnings management to obtain a higher return from its investment. Furthermore, controlling ownership and foreign ownership has a negative effect on earnings management. According to the "demand" hypothesis, public equity firms have a higher quality of earnings than private equity firms due to a stronger demand by their shareholders and creditors for quality reporting. Hence, a higher level of foreign ownership will reduce earnings management practices. 


\section{References}

Affan, Muhammad Wilda, Rosidi and Lilik Purwanti. (2017). The Effect of Ownership Structure on the Quality of Financial Reporting of Manufacturing Companies Listed in the IDX during the Period of 2013-2015. Imperial Journal of Interdisciplinary Research, Vol. 3, Issue 7. https://www.onlinejournal.in/IJIRV3I7/031.pdf

Ali, S. M., Salleh, N. M., \& Hassan, M. S. (2008). Ownership structure and earnings management in Malaysian listed companies: the size effect. Asian Journal of Business and Accounting, 1(2), 89-116. https://ukm.pure.elsevier.com/en/publications/ownership-structure-and-earnings-management-in-malaysian-listed-c

Bao, S. R., \& Lewellyn, K. B. (2017). Ownership structure and earnings management in emerging markets-An institutionalized agency perspective. International Business Review, 26(5), 828-838. https://doi.org/10.1016/j.ibusrev.2017.02.002

Bathala, C. T., Moon, K. P., \& Rao, R. P. (1994). Managerial ownership, debt policy, and the impact of institutional holdings: An agency perspective. Financial Management, https://www.coursehero.com/file/p1f43idg/REFERENSI-Bathala-C-T-KP-Moon-dan-R-P-Rao-1994-Managerialownership-debt-policy/

Bartov, E., Givoly, D., \& Hayn, C. (2002). The rewards to meeting or beating earnings expectations. Journal of accounting and economics, 33(2), 173-204.https://doi.org/10.1016/S0165-4101(02)00045-9

Charitou, A., Louca, C., \& Tsalavoutas, I. (2016). Corporate governance, agency problems, and firm performance: empirical evidence from an emerging European market. Agency Problems, and Firm Performance: Empirical Evidence from an Emerging European Market (April 8, 2016). http://dx.doi.org/10.2139/ssrn.2221612

Dechow, P. M., Sloan, R. G., \& Sweeney, A. P. (1995). Detecting earnings management. Accounting review, 193225.https://www.jstor.org/stable/248303?seq=1\#page_scan_tab_contents

Godfrey, J., Hodgson, A., Tarca, A., Hamilton, J., \& Holmes, S. (2010). Accounting theory. https://trove.nla.gov.au/work/6437538?q\&sort=holdings+desc\&_=1558158070908\&versionId=47056094

Guna, Welvin I. dan Arleen Herawaty. (2010).The effect of good corporate governance mechanisms, auditor independence, audit quality and other factors on earnings management. Business and accounting journals, 12 (1), 53 68.http://jurnaltsm.id/index.php/JBA/article/view/162

Obigbemi, I. F. (2017). Ownership Structure and the Earnings Management Practices of Nigerian Companies. Journal of Internet Banking and Commerce.http://www.icommercecentral.com/open-access/ownership-structure-and-earningsmanagement-practices-of-nigerian-companies.pdf

Ogbonnaya, A. K., Ekwe, M. C., \& Ihendinihu, J. U. (2016). Effect of Corporate Governance and Ownership Structure on Earnings Management of Brewery Industry. European Journal of Accounting, Auditing and Finance Research, 4(7), 35-45. https://www.eajournals.org/journals/european-journal-of-accounting-auditing-and-finance-research-ejaafr/vol-4issue-8-august-2016/effect-corporate-governance-ownership-structure-earnings-management-brewery-industry/

Sirat, H. (2012). Corporate governance practices, share ownership structure, and size on earning management. Journal of Economics, Business, and Accountancy Ventura, 15(1), 145-156.http://dx.doi.org/10.14414/jebav.v15i1.67

Warfield, T. D., Wild, J. J., \& Wild, K. L. (1995). Managerial ownership, accounting choices, and informativeness of earnings. Journal of accounting and economics, 20(1), 61-91.https://doi.org/10.1016/0165-4101(94)00393-J

Wiranata, Y. A., \& Nugrahanti, Y. W. (2013). The effect of ownership structure towards profitability of Indonesia manufacturing companies. Accounting and Finance Journal, 15 (1), 15-26. https://doi.org/10.9744/jak.15.1.15-26 